\title{
Literature review of audiovisual practices in Nursing education
}

\author{
Revisão de literatura sobre as práticas com audiovisuais na educação em Enfermagem \\ Revisión de la literatura sobre las prácticas con audiovisuales en la educación en Enfermería
}

\section{Américo de Araujo Pastor Junior' ORCID: 0000-0003-4709-1221}

\section{Claudia Mara de Melo Tavares'} ORCID: 0000-0002-8416-6272

'Universidade Federal Fluminense, Escola de Enfermagem Aurora de Afonso Costa. Niterói, Rio de Janeiro, Brazil.

How to cite this article:

Pastor Jr AA, Tavares CMM. Literature review of audiovisual practices in Nursing education.

Rev Bras Enferm [Internet]. 2019;72(1):190-9.

DOI: http://dx.doi.org/10.1590/0034-7167-2017-0890

\section{Corresponding Author:}

Américo de Araujo Pastor Junior

E-mail: americoapj@id.uff.br

Submission: 12-19-2017

Approval: 06-08-2018

\section{ABSTRACT}

Objective: to carry out a literature review to characterize the production in the Nursing area about the use of movies and videos in Nursing education, related to underlying communication assumptions and contents taught. Method: integrative bibliographic review carried out in the PUBMED databases, CAPES journal portal, and SCIELO online library, with studies from 2007 to 2016. Results: 36 articles were included, in which audiovisual resources are part of the research subject. There are predominance of validation and effectiveness studies, in which audiovisual resources are used mostly as a reproduction of reality, mainly to develop clinical skills, with the purpose of illustrating procedures or bringing students closer to real contexts of action. Final considerations: the results point to a weak theoretical support of most of the studies. It is suggested that more empirical research be conducted to offer more consistent contributions to Nursing teaching.

Descriptors: Nursing Education; Audiovisual Resources; Cinema as Subject; Educational Movies and Videos; Educational Technology.

\section{RESUMO}

Objetivo: realizar uma revisão da literatura para caracterizar a produção na área de Enfermagem sobre o uso de filmes e vídeos na educação em Enfermagem, relacionados a pressupostos de comunicação subjacentes e a conteúdos lecionados. Método: revisão bibliográfica integrativa realizada nas bases de dados $P U B M E D$, portal de periódicos da CAPES, e na biblioteca on-line SCIELO, com estudos de 2007 a 2016. Resultados: foram incluídos 36 artigos, em que os audiovisuais fazem parte do objeto de pesquisa. Há predominância de estudos de validação e efetividade, em que os audiovisuais são utilizados em maior parte como um reproduzir a realidade, principalmente para desenvolver competências clínicas, com o propósito de ilustrar procedimentos ou aproximar os estudantes de contextos reais de atuação. Considerações finais: os resultados apontam a uma fragilidade na sustentação teórica da maior parte dos estudos. Sugere-se a realização de pesquisas empíricas mais bem fundamentadas para oferecer contribuições mais consistentes ao ensino em Enfermagem.

Descritores: Educação em Enfermagem; Recursos Audiovisuais; Cinema como Assunto; Filmes e Vídeos Educativos; Tecnologia Educacional.

\section{RESUMEN}

Objetivo: realizar una revisión de la literatura para caracterizar la producción en el área de la Enfermería sobre el uso de películas y videos en la educación de Enfermería, relacionados a supuestos de comunicación subyacentes y a contenidos enseñados. Método: revisión bibliográfica integrativa realizada en las bases de datos PUBMED, portal de revistas de la CAPES, y en la biblioteca on line SCIELO, con estudios de 2007 a 2016. Resultados: se incluyeron 36 artículos, en los que los audiovisuales forman parte del objeto de investigación. Hay predominio de estudios de validación y efectividad, en los que los audiovisuales se utilizan en gran parte como un reproducir la realidad, principalmente para desarrollar competencias clínicas, con el propósito de ilustrar procedimientos o aproximar a los estudiantes de contextos reales de actuación. Consideraciones finales: los resultados apuntan a una fragilidad en la sustentación teórica de la gran parte de los estudios. Se sugiere la realización de investigaciones empíricas más bien fundamentadas para ofrecer contribuciones más consistentes a la enseñanza de Enfermería.

Descriptores: Educación en Enfermería; Recursos Audiovisuales; Cine como Asunto; Películas y Videos Educativos; Tecnología Educativa. 


\section{INTRODUCTION}

Over the last decades, videos and movies have been used more as a didactic resource in education. From educational videos, videorecording activities, use of commercial movies or TV programs, to podcasts of social networks, audiovisual resources have become very common tools in teaching and learning dynamics. This variety of uses and appropriations of audiovisual resources in classrooms is generally supported by the understanding that movies and videos can: allow the critical perception of society ${ }^{(1)}$; awakening and reinforcing student interest and student motivation ${ }^{(2)}$; carry everyday facts to the classroom; and open a privileged channel of access to the cognitive and affective levels ${ }^{(3)}$.

In Health education, these arguments have also been used with some frequency. Some papers bring the understanding that videos and movies are important resources to emotionally engage viewers ${ }^{(4)}$, to raise reflections on themes related to the humanization of health care ${ }^{(5)}$, and to be a resource for the development of communication skills ${ }^{(6)}$.

Specifically, in Nursing training, the use of movies and videos has been advocated for more than 30 years, highlighting ${ }^{(7)}$ advantages such as flexibility, possibility of playback, archiving, control of the point of view and way of presenting reality to students. In this understanding ${ }^{(7)}$, videos can be used to replace live presentations/ instructions, complement other teaching methods, and train skills. More recently, the movies have also been understood as facilitators of theoretical learning, resources for experimenting with social and cultural practices, to awaken interests and develop reflections on daily life ${ }^{(8)}$, as well as to offer Nursing training the possibility of students to contexts of care and to be sources of emotional and cognitive experiences ${ }^{(9)}$. Silva et al. $^{(10)}$ points out that the movies are facilitators for the visualization and understanding of the subject with psychiatric disorders, since they promote reflection and the projection of oneself in the other.

Narratives such as these, which are often based on the use of audiovisual resources in classrooms, are based on assumptions that have some limitations. The first of these limitations is pointed out by Sol Worth ${ }^{(11)}$, already in 1974, who questioned the insufficiency of empirical studies to support these arguments about the potentialities of images in their use in education. For the author, these arguments, in general, are supported by the belief in the universality of images to communicate to different cultures, ages and genders, the psychological and social superiority of images in communicating ("a picture is worth a thousand words").

In the context of Post-structuralist Cultural Studies, it is possible to define a second limitation, which concerns the communication model underlying the arguments questioned. Thus, based on Stuart Hall's ${ }^{(12)}$ criticism of the traditional model (communicationmessage-receiver), these arguments are based on the understanding of the unilinearity of communication and presuppose the passivity of the viewers/receivers. This becomes clear exactly when the videos are understood as encouragement capable of motivating, provoking reflections, or even replacing an experience in some professional context. From this perspective, it would be up to viewers to assimilate content transmitted via audiovisual resources, consisting of behavioralist encouragement/ response dynamics. In response to this, Hall proposes to think of communication in its complexity, multilinearity, and mainly by understanding viewers as active in producing the meanings of their experiences from movies/video.

Understanding such limitations in understanding the teaching and learning dynamics in which movies and videos are used, it is relevant to identify in the scientific production that understandings and assumptions have guided the uses of videos and movies in Nursing training and to understand how these practices have been related to curricular content and proposed activities. Thus, following our previous experience in medical education ${ }^{(13)}$, the present study consists of a bibliographical review on the uses and appropriations of audiovisual resources in Nursing training, to investigate how the area has appropriated these resources, under which conceptions, objectives and in which disciplinary contexts.

\section{OBJECTIVE}

To carry out a literature review to characterize the production in the Nursing area about the use of movies and videos in Nursing education, related to underlying communication assumptions and contents taught.

\section{METHOD}

For the development of the present study an integrative systematic bibliographical review was developed. A bibliographical review aims to determine what research present about a topic, what they do not, what is known and what is not known; find gaps in knowledge; and synthesize results ${ }^{(14)}$. Specifically, the integrative bibliographic review offers the opportunity to know the evolution of the theme over time and, with this, to visualize possible research opportunities ${ }^{(15)}$. The review can be structured respecting the following 6 steps to carry out this type of review ${ }^{(15)}$ : identification of the theme and selection of the research question; establishment of the inclusion and exclusion criteria; identification of pre-selected and selected studies; categorization of selected studies; analysis and interpretation of results; presentation of knowledge review/ synthesis. This review followed to PRISMA' ${ }^{1}$ guidelines.

The selection was based on the survey of indexed works to the PUBMED database (https://www.ncbi.nlm.nih.gov/pubmed/) and published in journals indexed to the QualisCapes strata of the Nursing area, found through the journal portal of CAPES and SCIELO.

The search terms were "vídeo", "filme" and "cinema" in Portuguese-language journals, and "video", "movie", "film" and "cinema" in English-language journals. Only papers published in the last ten years were considered. Thus, the survey was carried out in January 2017 and, for this reason, contemplates works published until December 2016. Although there is the defense that a review study should be done in the last five or seven years ${ }^{(14-15)}$, it is understood that this period would also contribute to a perception of production history, without broadening the corpus of research.

Subsequently, the abstracts were read, from which articles that did not specifically focus on Nursing teaching and/or the movies and videos were not included in the research objects were excluded. In Chart 1, the following are the journals, classifications, countries of origin and total of publication found and selected for the study. 
Chart 1 - Journals selected for the literature review

\begin{tabular}{|l|c|l|c|c|}
\hline \multicolumn{1}{|c|}{ JOURNAL } & CODE & \multicolumn{1}{|c|}{ LEVEL } & FOUND & SELECTED \\
\hline Escola Anna Nery Revista de Enfermagem & EANRE & B1 Nursing. & 3 & 2 \\
\hline Revista Latino-americana de Enfermagem & RLE & A1 Nursing. & 1 & 1 \\
\hline Revista da Escola de Enfermagem da USP & REEU & A2 Nursing. & 3 & 0 \\
\hline Revista Brasileira de Enfermagem & REBEn & A2 Nursing. & 7 & 1 \\
\hline Texto \& Contexto Enfermagem & TCE & A2 Nursing. & 7 & 2 \\
\hline Cadernos de Saúde Pública & CSP & A2 Nursing. & 2 & 0 \\
\hline Nurse Education in Practice & NEP & A1 Nursing. & 26 & 8 \\
\hline Nurse Education Today & NET & A1 Nursing. & 28 & 15 \\
\hline Journal of Continuing Education in Nursing & JCEN & A1 Nursing. & 2 & 0 \\
\hline Journal of Trauma Nursing & JTN & A2 Nursing. & 1 & 1 \\
\hline International Journal of Medical Informatics & IJMI & A2 Nursing. & 1 & 1 \\
\hline Journal of Advanced Nursing & JAN & A1 Nursing. & 1 & 1 \\
\hline Computer, Informatics, Nursing & CIN & A1 Nursing. & 1 & 1 \\
\hline Contemporary Nursing & CN & A1 Nursing. & 1 & 0 \\
\hline Nurse Educator & NE & A1 Nursing. & 4 & 36 \\
\hline Total & & & 2 \\
\hline
\end{tabular}

\section{RESULTS}

From the selection criteria of the material for the analysis, 36 studies were chosen. When analyzed under the selected questions, they offered inputs for the perception of tendencies and gaps in the scientific production of the journals with the best evaluation in the Brazilian context.

In the Chart 2 the papers selected for this study are listed.

Initially, among the articles selected, there are 2 literature review studies, both from NET magazine. The first one ${ }^{(35)}$ analyzes (in 11 papers) the use of commercial movies in Nursing education, attentive to the concept of cinurseducation, to better define this term (cinema, nurse and education). The author relates the use of movies with the goals of developing a more student-

Based on the reading of the selected papers, we initially sought to answer the following questions: 1) In what type of study does the work consist? 2) What conceptions do they bring about videos and movies and their uses in Nursing education? 3) How is the video researched? 4) The use/study is related to what course of Nursing? 5) What is the pedagogic objective of the use of videos/movies? centered, experiential, reflexive, and problem-solving education. The second one ${ }^{(40)}$, has developed a review (in 54 papers) on the use of commercial movies in education in Health Sciences. In this work, the main result points to the insufficiency of studies that demonstrate the usefulness and validity of the use of movies as didactic resources despite their recurrent use.

Chart 2 - Papers selected for the review

\begin{tabular}{|c|c|c|c|}
\hline TITLE & YEAR & REF. & JOURNAL \\
\hline Use of film as a teaching-learning strategy on people with disabilities: perception of Nursing students & 2012 & (9) & \multirow{2}{*}{ EANRE } \\
\hline Effect of an educational video on student's knowledge about oral hygiene of patients undergoing chemotherapy & 2015 & (16) & \\
\hline Camera and action in performing the central venous catheter dressing & 2015 & (17) & RLE \\
\hline Validation of an educational video to promote attachment between HIV-positive mother and her child & 2011 & (18) & RBEN \\
\hline The process of living in the movies: old age, sexuality and memory in Copacabana & 2007 & (19) & \multirow{2}{*}{ TCE } \\
\hline Learning in mental health through videographic production: an experience report & 2013 & (20) & \\
\hline $\begin{array}{l}\text { A focus group study of the use of video-recorded simulated objective structured clinical examinations in nurse } \\
\text { practitioner education }\end{array}$ & 2010 & (21) & \multirow{8}{*}{ NEP } \\
\hline Challenging the shock of reality through digital storytelling & 2011 & (22) & \\
\hline $\begin{array}{l}\text { Snapshots of simulation: Creative strategies used by Australian educators to enhance simulation learning experiences for } \\
\text { Nursing students }\end{array}$ & 2013 & (23) & \\
\hline $\begin{array}{l}\text { Comparing the effectiveness of video-assisted oral debriefing and oral debriefing alone on behaviors by undergraduate } \\
\text { Nursing students during high-fidelity simulation }\end{array}$ & 2014 & (24) & \\
\hline Teaching midwife students how to break bad news using the cinema: An Italian qualitative study & 2015 & (25) & \\
\hline An education intervention to improve Nursing students' understanding of medication safety & 2015 & (26) & \\
\hline Madness in the movies: An evaluation of the use of cinema to explore mental health issues in nurse education & 2016 & (27) & \\
\hline The viewing room: A lens for developing ethical comportment & 2016 & (28) & \\
\hline Using on-line video clips to enhance self-efficacy toward dealing with difficult situations among Nursing students & 2006 & (29) & \multirow{4}{*}{ NET } \\
\hline Video streaming: Implementation and evaluation in an undergraduate Nursing program & 2008 & (30) & \\
\hline $\begin{array}{l}\text { A multi-method study to determine the effectiveness of, and student attitudes to, online instructional videos for } \\
\text { teaching clinical Nursing skills }\end{array}$ & 2009 & (31) & \\
\hline Video-based self-assessment: Implementation and evaluation in an undergraduate Nursing course & 2009 & (32) & \\
\hline
\end{tabular}




\begin{tabular}{|c|c|c|c|}
\hline TITLE & YEAR & REF. & JOURNAL \\
\hline Web-based video and feedback in the teaching of cardiopulmonary resuscitation & 2012 & (33) & \multirow{11}{*}{ NET } \\
\hline $\begin{array}{l}\text { Effect of a video on developing skills in undergraduate Nursing students for the management of totally implantable } \\
\text { central venous access ports }\end{array}$ & 2012 & (34) & \\
\hline Learning concepts of cinenurducation: An integrative review & 2012 & (35) & \\
\hline $\begin{array}{l}\text { A pilot project in distance education: Nurse practitioner students' experience of personal video capture technology as } \\
\text { an assessment method of clinical skills }\end{array}$ & 2013 & (36) & \\
\hline $\begin{array}{l}\text { Online video in clinical skills education of oral medication administration for undergraduate student nurses: A mixed } \\
\text { method, prospective cohort study }\end{array}$ & 2013 & (37) & \\
\hline $\begin{array}{l}\text { Attitudes toward Video-Assisted Debriefing after simulation in undergraduate Nursing students: An application of Q } \\
\text { methodology }\end{array}$ & 2014 & (38) & \\
\hline $\begin{array}{l}\text { Improving Chinese Nursing students' communication skills by utilizing video-stimulated recall and role-play case } \\
\text { scenarios to introduce them to the SBAR technique }\end{array}$ & 2016 & (39) & \\
\hline Literature review: Use of commercial films as a teaching resource for Health Sciences students & 2016 & (40) & \\
\hline $\begin{array}{l}\text { Nursing students' preferences of strategies surrounding cinenurducation in a first-year child growth and development } \\
\text { courses: A mixed method study }\end{array}$ & 2016 & (41) & \\
\hline $\begin{array}{l}\text { Piloting the feasibility of head-mounted video technology to augment student feedback during simulated clinical } \\
\text { decision-making: An observational design pilot study }\end{array}$ & 2016 & (42) & \\
\hline Use of videos to support teaching and learning of clinical skills in Nursing education: A review & 2016 & (43) & \\
\hline Practitioner Perceptions of Trauma Video Review & 2013 & (44) & JTN \\
\hline Evaluation of an interactive web-based Nursing course with streaming videos for medication administration skills & 2014 & (45) & IJMI \\
\hline $\begin{array}{l}\text { Effects of video-feedback on the communication, clinical competence and motivational interviewing skills of practice } \\
\text { nurses: a pre-test post-test control group study }\end{array}$ & 2014 & (46) & $J A N$ \\
\hline Mobile-Based Video Learning Outcomes in Clinical Nursing Skill Education: A Randomized Controlled Trial & 2016 & (47) & CIN \\
\hline Using Film, Television, and Other Media to Teach Management and Leadership Concepts & 2013 & (48) & \multirow{3}{*}{$N E$} \\
\hline Cinematic Technology: The Role of Visual Learning & 2011 & (49) & \\
\hline Creating a Shared Experience Using Movies in Nursing Education & 2008 & (50) & \\
\hline
\end{tabular}

Regarding the selected national production, especially considering the discrepancy of this production in relation to the international, it is possible to think that, despite the recurrent use of videos and movies in Nursing education, the study of these technologies is still not clearly defined as a topic of interest of the area. There were 30 international articles selected (out of 65 found) and 6 nationals selected (out of 23 found). The national production has an increased concentration in the last 5 years. Despite the small amount of publications, it is possible to observe a tendency of increase of publications on the topic searched here. Meanwhile, international production has been a little more spread in the last 10 years, despite being larger in the last 2 years.

\section{What are the type of the studies analyzed? How is the video searched?}

At this stage of research, it was observed the type of research as well as how the video was studied or was part of the research. A first point to note is the predominance of empirical studies over those that are only theoretical. Only TCE (1), NEP (2), NET (3) and $\mathrm{NE}$ (1) journals presented theoretical studies, totaling six studies, from the universe of 30 analyzed.

The proportion between empirical and theoretical studies is practically the same in national and international publications, that is, less than $20 \%$ of the selected studies are theoretical. It remains to know what is the quality and scope of these empirical studies.
The empirical studies included: validation studies by specialists (3), comparative studies with other technologies or practices (10), studies of efficacy of uses (7) and case studies and characterization of experiences (9). It is possible to note a national trend towards validation by specialists. These studies ${ }^{(17-18,20)}$ consist of presenting some proposal of educational activity with the use of movies or videos and request that professionals of the area or researchers of the Nursing area evaluate and validate such proposal. It is interesting to note that these studies only counted on validators of the Nursing area, no longer counting on people from the area of Education, Technologies and Communication, an aspect that weakens the presented validations. In addition, validation tools leave some doubts, as the evaluation questions may be more focused on the preferences and content of the movies, and the effectiveness of the educational dynamics with the use of movies and videos or even the role videos/movies in the activities.

International studies have tended to be comparative studies, efficacy studies and case studies. In these studies, videos are compared to other educational technologies, ranging from lectures $^{(23,30)}$ and observation of care ${ }^{(31-32,34)}$ to readings of texts ${ }^{(24)}$ and care simulations in Role-Play dynamics ${ }^{(39)}$. There was also some recurrence of studies in which learning was assessed in pre and post-tests at the display of a particular film or video ${ }^{(16,41,46-47)}$. Also noteworthy was the number of case presentation studies and video experiences pointing to advantages and peculiarities found ${ }^{(15,22,25,33,45)}$. These data will be better understood following the presentation of results. 


\section{What conceptions do they bring about videos and movies and their uses in Nursing education?}

From our analysis 13 non-exclusive categories appeared. In this sense, videos can: reproduce reality, encourage reflection, raise awareness, share experiences, be instruments to explore reality, transmit information, substitute writing, facilitate teaching, contribute to the production of subjectivities, arouse students' interest , transpose space-time limits, change behavior, aid self-evaluation and reflection. Figure 1 shows the occurrences of these categories.

Conceptions that bring the use of movies and videos in Nursing education

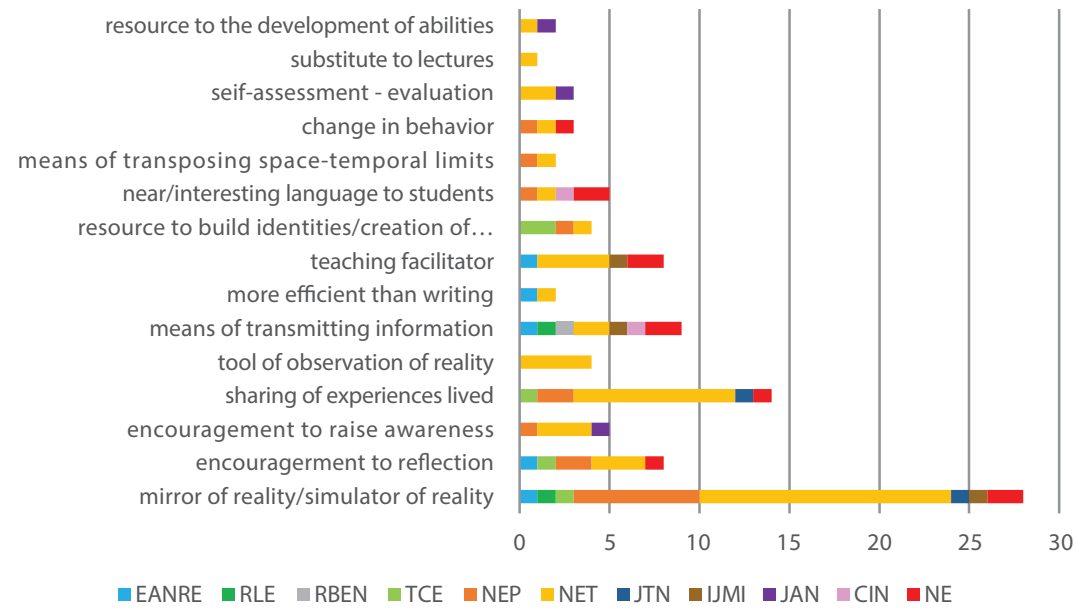

Figure 1 - Ways of studying movies

The most frequent conception in these papers (national and international) was the possibility of movies and videos reproducing/transporting reality into the classroom (works that do this). The videos and movies would be mainly mirrors/reflections of reality ${ }^{(19-21,23-26,28-40,42-45,49-50)}$, reality simulators ${ }^{(17,23-24,34,39,43,45,50)}$ and would enable students to experience ${ }^{(19,22,25,28,29,35,39-44,49-50)}$ and explore ${ }^{(31-32,34,36-38)}$ distant realities of their classrooms and experiences ${ }^{(15,28,35,49-50)}$. In this sense, these media would offer access to an experiential universe in which students could immerse themselves in care settings, but in the safe and controlled classroom environment ${ }^{(34-35)}$.

Also, regarding this category, it was possible to observe some differences when referring to videos or movies. The movies were mainly related to a more existential dimension in presenting contexts of action, if returning to encourage reflection and awareness, and offer experiences to the students. This experiential dimension is also strongly related to the categories sharing experiences, producing subjectivities ${ }^{(20)}$ and identities ${ }^{(19)}$, as well as encouraging reflection ${ }^{(22,35,46,49)}$. It is understood, in these works, that by experiencing narratives presented by the movies, students would intensify the process of personal and professional maturation ${ }^{(39)}$.

When papers was related to videos as reproducers of reality, these papers were more intended to illustrate a procedure or type of care ${ }^{(26,28,33,34,43,47-48)}$, to be memory devices ${ }^{(32-33,36,38,41)}$, to transmit information more easily ${ }^{(15,24,32-33,37,40-41,47)}$, and to offer students the opportunity to review their care $\mathrm{e}^{(33,37-38)}$ and thus perform a selfevaluation, that is, being able to explore reality by transposing limits of space and time ${ }^{(21)}$ (especially when related to distance education). These conceptions, more frequent in NET, seem to be strongly influenced by the work of McSweeney ${ }^{(7)}$, published in this same journal (paper excluded from our sample), 30 years ago, which defended some advantages for the use of videos in education in Nursing, such as flexibility, immediate access, archiving of information, presentation of reality and control of the point of view. This gives indications that such conceptions seem to have evolved very little since the publication of this paper. It should be noted that NET also had greater recurrences of works on movies and with epistemological orientation different from that of the videos.

It is important to say that in the categories transmitting information, facilitating teaching, arousing interests and changing behaviors, the behaviorist perspective in using these educational technologies becomes clear. This tendency was greater in national publications, although it did not predominate. These objectives reveal a perception of the students as passive spectators who should only follow the guidelines of the videos or repeat the behaviors/actions presented in them ${ }^{(35,49)}$.

\section{Disciplines and areas of knowledge of the uses of movies and videos in Nursing}

In this topic, the interest was to identify the context of using movies and videos. In the next topic, the interest will be on the objectives of the uses in those disciplines and areas of knowledge. Figure 2 shows the 16 areas of knowledge and the occurrences by journal.

National publications have tended to turn to areas of medical specialties (Oncology ${ }^{(16)}$, Gerontology ${ }^{(19)}$, Oral Health ${ }^{(16)}$, HIV $^{(18)}$, Mental Health ${ }^{(20,27)}$, Adult Health ${ }^{(20)}$, Obstetrics and Pediatrics $\left.{ }^{(18)}\right)$. The videos on Oncology, Adult Health, Oral Health and Obstetrics were once again broadcasting content, illustrating and presenting procedures that students were expected to learn. One of the HIV videos was also intended to bring information to the mothers of patients and sensitize them. In the case of Mental Health, Gerontology and on patients with impairments, the papers studied how the movies can offer experiences to the students. In this way, students were supposed to be able to better understand their future patients, from their perspectives (empathic posture) regarding mental health care, elderly patients and people with impairments.

In international studies, the context of using videos and movies was predominantly in disciplines focused on the development of clinical skills and multidisciplinary areas of knowledge. There was a greater frequency of use of videos to illustrate and exemplify the administration of medications ${ }^{(37)}$, evaluation ${ }^{(23)}$ and clinical procedures (e.g., checking vital signs ${ }^{(32)}$ ). In the evaluation, the film was used mainly as a means for students to be able to review their performed care ${ }^{(21,23-24,28-29,38,46)}$, to have feedback ${ }^{(23,42)}$ and thus to improve their practice. Although the former predominated, movies and videos were used to train students for care. In this 
category, the movies were understood as experiential universe in which the spectators could develop knowledge, know other realities $^{(21-24,29,48,50)}$, reflect $^{(15,20,22,25,27,32,35,38,40,50)}$ and better develop social skills and communicative skills ${ }^{(21)}$, and have contact with emotions mobilized in contact with the other ${ }^{(25,37)}$. Both videos and movies have become an environment to encourage professional practice and spaces to produce reflections on their future practice.

Discipline or field of knowledge of the uses of movies

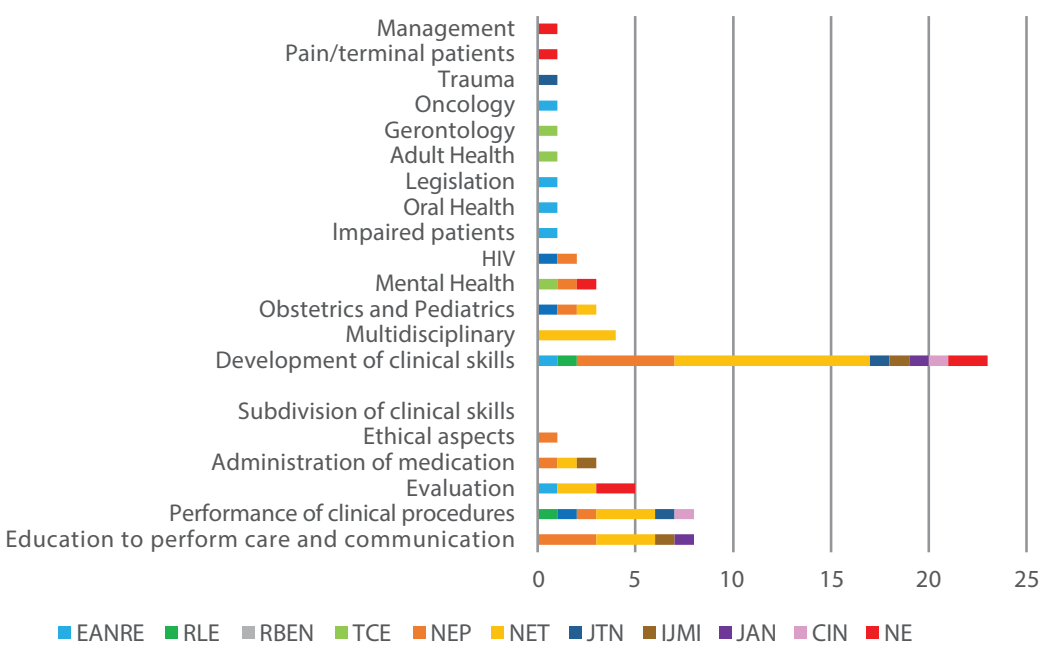

Figure 2 - Distribution by discipline or areas of knowledge of uses of movies

\section{Pedagogical objective of the use of videos/movies in Nursing training}

In order to characterize the pedagogical objective of the use of these media in Nursing training, eight categories emerged from the data: illustrate/demonstrate contents ${ }^{(16,24,26,28,41)}$, care $^{(24,29,38)}$ and procedure $\mathrm{e}^{(17,23-24,26,33-34,43)}$; approximate the daily reality and experience of the other ${ }^{(16,34,43)}$; provoke reflection/discussion $^{(15,20,22,27,32,35,45,49-50)}$; offer self-perception, evaluation, review of clinical behaviors ${ }^{(21,23-24,33)}$; create an environment encouragement of care ${ }^{(23-24,33)}$; transmit information ${ }^{(16-18,44,46-48)}$; raise awareness

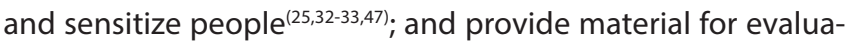
$\operatorname{tion}^{(23-24,32-33,36)}$. Some of these categories have already appeared in previous topics. These categories are quantified in Figure 3.

Pedagogical objectives of the use of movies/videos

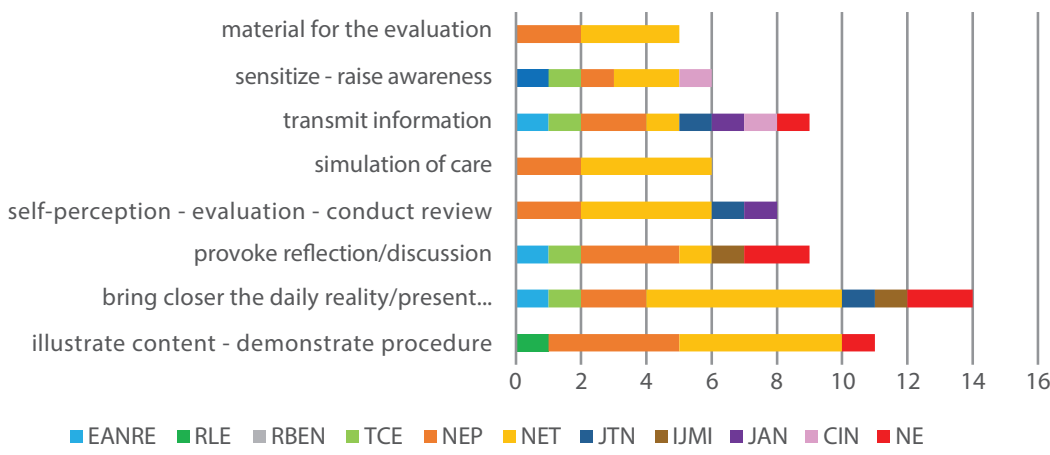

Figure 3 - Pedagogical objectives of movies
Reinforcing the previously presented results, the objectives of promoting an approximation to (another) reality, or a qualified perception of everyday reality itself, were more common, as well as to illustrate content and demonstrate procedures. The first, mostly occurred with the uses of movies and the second, with the uses of videos.

With movies, the approach to reality also serves the purpose of provoking reflection and discussion, as well as seeking to raise awareness and sensitize people. These objectives are mainly related to the purpose of seeking to construct a differentiated look to the reality already inhabited and, thus, the students can have their attentions called to aspects that demand discussion and reflection.

The videos also followed tendencies from previous topics and were used as means of illustrating, transmitting information and demonstrating performance of procedures. In addition, the videos were repeatedly used to film the students' performance for the subsequent evaluation, revision. That is, in both types of appropriations of videos and movies, the broader tendency of appropriation of videos in Nursing education was followed.

\section{DISCUSSION}

No references to the quality of the viewer were found in the selected articles. In most papers analyzed, it became clear that students would passively follow the objectives and proposals of the uses of movies and videos. And when that did not happen, they should re-study the video/film or usage dynamics to get it adjusted.

The recurrence of validation and comparative studies demonstrates that non-learning is understood as a failure of the material and not as the possibility for students to actively produce senses that the desired objectives escape with the uses of movies and videos. It should also be noted that the validity studies only evaluated if the contents agreed, and for that reason they were only evaluated by nurses. This practice tends to simplify the complexity of communication involving movies and videos in the classroom, as well as to minimize the role of viewers in producing meaning. It would be interesting that, in this type of study, professionals from related areas and other expertises were also included and that reception studies complemented the conclusions about the analyzed activities.

In the international literature, the use of videos as means of training nurses to perform procedures and to communicate with the patient prevailed. In the uses of movies were recurrent the strategies of sensitization, awareness and production of reflection. In both there was the goal of the media being encouragement and resulting in a behavior, perception and/or certain knowledge to be produced by studentviewers. This reinforces the idea of a traditional conception of communication that takes viewers/students as passive in the teaching-learning dynamic involving videos and movies, which follows, therefore, the tendency of a broader field of education. 
Among the conceptions that guided the uses of videos and movies, the most frequent was the understanding of movies as mirrors of reality, simulators of reality, experiential universe for students. This understanding goes beyond the limitations of the assumptions pointed out by Woth ${ }^{(10)}$ and offers the studies of the area a possibility of overcoming the traditional model of communication, understanding the complexity of the experiences and existences of the students in the classroom and their relationship with the movies and videos. However, this assumption that movies/videos are an experiential universe, or a reproduction of reality is also not satisfactorily grounded in empirical data. Some of studies arrive at this result but depart from that same place as presupposed. In this sense, they consist of tautologies. It is important to develop further empirical research where the assumption in question is better studied and sustained.

The literature review studies analyzed in the present study agree that there is an insufficiency of studies of the use of these media in Nursing training. This insufficiency is configured not in quantity, but in the quality of the published papers. There is a predominance of empirical studies, but a lack of reflections on the results of these surveys. Even these reviews have little depth or a restricted sample of work. This paper did not attempt to deal with this demand. Our proposal was more directed to characterize some deficiencies of the studies on uses of movies and videos in Nursing.

Another aspect worth mentioning is the existence of few national surveys on the use of these educational technologies. Two international journals had a much larger amount of work and superior quality of results and discussions in relation to national production. Domestic production still seems to be more concerned with validating the few experiments that have been done than on developing new anchored proposals and more robust studies on the uses of these technologies.

\section{Study limitations}

This study has the limitation of having only articles published in journals indexed and evaluated by the QualisCapes system (https://sucupira.capes.gov.br/sucupira/public/consultas/coleta/ veiculoPublicacaoQualis/listaConsultaGeralPeriodicos.jsf). The purpose of this choice was to focus on works published in the most relevant journals for Nursing. The purpose of this choice was to focus on the works published in the most relevant journals for Nursing.

Another limitation was the lack of inclusion of three articles from two indexed journals, but which were not freely available or available through the CAPES Portal Periódicos (http://www. periodicos.capes.gov.br). This aspect does not significantly compromise the results, considering the total of articles analyzed.

\section{Contributions to the Nursing, Health or Public Policy sectors}

From the analysis of 36 articles, the study contributes to the perception of tendencies in the use of movies and videos in Nursing education, ideas that support these uses in different moments, knowledge and spaces of Nursing education. Such information, besides offering a critical perception and a questioning about these uses, can contribute to the elaboration of new forms of use, as well as to the innovation of classes that appropriate videos in the training in Nursing and other areas of training in Health. In the present study it is possible to perceive, in the international literature, a significant variety of reports on the use of movies and videos in Nursing education, which was not present in the national literature.

\section{FINAL CONSIDERATIONS}

In the present study, we observed some tendencies in the scientific production on the use of movies and video in Nursing training. The movies are recurrently understood as means of accessing the reality of the health service, experiencing events still distant to students (such as Oncology and Geriatrics situations) and understanding mental states of Mental Health patients. The videos are mostly used as an evaluation/self-assessment tool and training to perform procedures and an illustration of aspects related to the nurse's clinical practice.

These uses are usually guided by communication understandings that are not consistent with the complexity of the health service for which students are prepared. In this service, professionals are expected to have autonomy (Art.14-I of the National Curricular Guidelines of the Nursing Undergraduate Program of 2001), reflective practice and critical capacity. However, in their formation, students have been taken as passive in the production of knowledge, especially in the dynamics involving the use of movies and videos. It is at this point that the inclusion of movies and videos in Nursing training possibly has its greatest contribution, that is, the provision of an active and relatively autonomous space of production of knowledge, in which students can reflect on their practices, about themselves, and have a critical posture in relation to the contents and practices studied.

In view of the results discussed here, it is clear the relevance of further research on the use of movies and videos in Nursing training, as well as in training for the performance of procedures, as a means of evaluation, illustration or narrative that offers a symbolic universe in that students can actively develop reflections and better develop themselves professionally and personally. In order to do so, it is reinforced the need for studies that not only contain more consistent theoretical bases, but which also have empirical designs dedicated to accounting for the Brazilian educational complexity, and thus include students as active producers of this dynamic, not only as spectators of movies and videos, but as active and autonomous in their production of knowledge.

Reinforcing results from previous studies, it is notable that movies and videos have been repeatedly referred to as innovative resources in education at various levels and quality of training. There is an imbalance between the proposals that highlight the advantages and potentialities for the use of videos in education and the studies on the effective use of these media in the dynamics of teaching and learning. Even studies that, on an empirical basis, do not deal clearly with their assumptions and are limited to validating an educational practice with movies and videos. Moreover, in the 
designs of these surveys there is not always a clear understanding of the difference between education in movies/videos and education with movies/videos. That results in inaccuracies in the conclusions and possible contributions to think the uses of these medias and even to understand in what innovations they can consist.

\section{FUNDING}

This study was funded by the CAPES financial aid, in the context of the National Program of Post-Doctorate (Programa Nacional de Pós-Doutorado).

\section{REFERÊNCIAS}

1. Hodge R, Kress G. Social semiotics. 2nd ed. Porto Alegre: Artmed; 1996. 280 p.

2. Ferrés J. Vídeo e Educação. 2nd ed. Porto Alegre: Artmed; 1996.

3. Arroio A, Giordan M. O vídeo educativo: aspectos da organização do ensino. Quim Nova [Internet]. 2006 [cited 2017 Nov 23];24:8-11. Available from: http://qnesc.sbq.org.br/online/qnesc24/eqm1.pdf

4. Blasco P, Gallian D, Roncoletta A, Moreto G. [Movies for medical students: an effective and affective resource in humanistic medical education]. Rev Bras Educ Méd [Internet]. 2005 [cited 2017 Nov 23];29(2):119-128. Available from: http://educacaomedica.org.br/UserFiles/ File/2005/volume29_2/cinema_para_estudante.pdf Portuguese.

5. Klemenc-Ketis and Kersnik. Using movies to teach professionalism to medical students. BMC Med Educ [Internet]. 2011 [cited 2015 Nov 9];11:60 Available from: https://doi.org/10.1186/1472-6920-11-60

6. Wong R, Saber S, Ma I, Roberts J. Using television shows to teach communication skills in internal medicine residency. BMC Med Educ. 2009 [cited 2015 Nov 9];9:9. Available from: https://doi.org/10.1186/1472-6920-9-9

7. McSweeney P. Sight and sound ... any use for video found? Part 1. Video-a technology spurned. Nurse Educ Today [Internet]. 1986 [cited 2017 Nov 23]; 6(4):172-5. Available from: https://doi.org/10.1016/0260-6917(86)90006-7

8. Tavares AMF, Larocca LM, Kalinowski CE, Bernardino E. [Cinema: teaching-learning strategy in the discipline of nursing history]. Univ Human [Internet]. 2017 [cited 2017 Nov 23];11(2):39-48. Available from: doi:10.5102/univhum.v11i2.2505 Portuguese.

9. Oliveira P, Mariano M, Rebouças C, Pagliuca L. [The use of movie as a strategy for teaching-learning about people with impairments: perception of nursing students]. Esc Anna Nery [Internet]. 2012 [cited 2017 Nov 23];16(2):297-305. Available from: http://dx.doi. org/10.1590/S1414-81452012000200013 Portuguese

10. Nicolau ARS, Camillo SO, Maiorino FT, Nóbrega MP. [The movies as pedagocical resource for the psychiatric nursing]. Rev Enferm Cent $O$ Min [Internet]. 2014 [cited 2017 Nov 23];4(1):983-92. Available from: http://www.seer.ufsj.edu.br/index.php/recom/article/view/553/573 Portuguese

11. Worth S. The Uses of Film in Education and Communication. In: Olson D. Media and symbols: the forms of the expression, communication, and educations. Chicago: University of Chicago Press; 1981. p 108-133.

12. Hall S. Enconding/decoding. In: Centre for Contemporary Cultural Studies, editors. Culture, Media, Language: Working Papers in Cultural Studies, 1972-79 London: Hutchinson, p. 128-38.

13. Pastor Junior AA, de Rezende Filho LA, Pereira MV, Bastos WG. [Movie and video appropriation in medical education]. Interf Educ [Internet]. 2016 [cited 2017 Nov 23];7(20):159-77. Available from: http://dx.doi.org/10.26514/inter.v7i20.806 Portuguese.

14. Ollhoff J. How to write a literature review. 1st ed. Farmington: Sparrow Media Group; 2011. 30 p.

15. Manual Revisão Bibliográfica Sistemática Integrativa: a pesquisa baseada em evidências [Internet]. 1st ed. Belo Horizonte: Grupo Anima Educação; 2014 [cited 2017 Nov 23]. 63 p. Available from: http://disciplinas.nucleoead.com.br/pdf/anima_tcc/gerais/manuais/manual_ revisao.pdf

16. Stina A, Zamarioli C, Carvalho E. Effect of educational video on the student's knowledge about oral hygiene of patients undergoing chemotherapy. Esc Anna Nery [Internet]. 2015 [cited 2018 Nov 03];19(2):220-225. Available from http://dx.doi. org/10.5935/1414-8145.20150028

17. Ferreira M, Godoy S, Góes F, Rossini F, Andrade D. Lights, camera and action in the implementation of central venous catheter dressing. Rev Lat Am Enfermagem [Internet]. 2015 [cited 2018 Nov 03];23(6):1181-1186. Available from: doi:10.1590/0104-1169.0711.2664

18. Barbosa RM, Bezerra AK. [Validation of an educational video for the promotion of attachment between seropositive HIV mother and her child]. Rev Bras Enferm [Internet]. 2011 [cited 2017 Nov 29]; 64(2):328-34. Available from: http://dx.doi.org/10.1590/S003471672011000200017 Portuguese

19. Oliveira MLC, Oliveira SRN, Iguma LT. [The living process in the movies: aging, sexuality, and memories in Copacabana]. Texto Contexto Enferm [Internet]. 2007 [cited 2017 Nov 29];16(1):157-62. Available from: http://dx.doi.org/10.1590/S0104-07072007000100020 Portuguese

20. Machado DM, Gottems LBD Pires MRGM. Learning mental helth through videography production: an experimential report. Texto Context Enferm [Internet]. 2013 [cited 2017 Nov 29];22(4):1205-13. Available from: http://dx.doi.org/10.1590/S0104-07072013000400040

21. Barratt J. A focus group study of the use of video-recorded simulated objective structured clinical examinations in nurse practitioner education. Nurse Educ Pract [Internet]. 2010 [cited 2017 Jul 17];10(3):170-5. Available from: https://doi.org/10.1016/j.nepr.2009.06.004 
22. Stacey G, Hardy P. Challenging the shock of reality through digital storytelling. Nurse Educ Pract [Internet]. 2011 [cited 2017 Jul 17];11(2):159-64. Available from: https://doi.org/10.1016/j.nepr.2010.08.003

23. McAllister M, Levett-Jones T, Downer T, Harrison P, Harvey T, Reid-Searl K et al. Snapshots of simulation: Creative strategies used by Australian educators to enhance simulation learning experiences for nursing students. Nurse Educ Pract [Internet]. 2013 [cited 2017 Jul 17];13(6):567-72. Available from: https://doi.org/10.1016/j.nepr.2013.04.010

24. Grant J, Dawkins D, Molhook L, Keltner N, Vance D. Comparing the effectiveness of video-assisted oral debriefing and oral debriefing alone on behaviors by undergraduate nursing students during high-fidelity simulation. Nurse Educ Pract [Internet]. 2014 [cited 2017 Jul 17];14(5):479-84. Available from: https://doi.org/10.1016/j.nepr.2014.05.003

25. Fieschi L, Burlon B, De Marinis M. Teaching midwife students how to break bad news using the cinema: An Italian qualitative study. Nurse Educ Pract [Internet]. 2015 [cited 2017 Jul 17];15(2):141-7. Available from: https://doi.org/10.1016/j.nepr.2015.01.008

26. Hewitt J, Tower M, Latimer S. An education intervention to improve nursing students' understanding of medication safety. Nurse Educ Pract [Internet]. 2015 [cited 2017 Jul 17];15(1):17-21. Available from: https://doi.org/10.1016/j.nepr.2014.11.001

27. McCann E, Huntley-Moore S. Madness in the movies: An evaluation of the use of cinema to explore mental health issues in nurse education. Nurse Educ Pract [Internet]. 2016 [cited 2017 Jul 17];21:37-43. Available from: https://doi.org/10.1016/j.nepr.2016.09.009

28. McAllister M, Levett-Jones T, Petrini M, Lasater K. The viewing room: A lens for developing ethical comportment. Nurse Educ Pract [Internet]. 2016 [cited 2017 Jul 17];16(1):119-24. Available from: https://doi.org/10.1016/j.nepr.2015.10.007

29. McConville S, Lane A. Using on-line video clips to enhance self-efficacy toward dealing with difficult situations among nursing students. Nurse Educ Today [Internet]. 2006 [cited 2017 Jul 17];26(3):200-8. Available from: https://doi.org/10.1016/j.nedt.2005.09.024

30. Bennett $P$, Glover P. Video streaming: Implementation and evaluation in an undergraduate nursing program. Nurse Educ Today [Internet]. 2008 [cited 2017 Jul 17];28(2):253-8. Available from: https://doi.org/10.1016/j.nedt.2007.04.005

31. Kelly M, Lyng C, McGrath M, Cannon G. A multi-method study to determine the effectiveness of, and student attitudes to, online instructional videos for teaching clinical nursing skills. Nurse Educ Today [Internet]. 2009 [cited 2017 Jul 17];29(3):292-300. Available from: https://doi.org/10.1016/j.nedt.2008.09.004

32. Yoo M, Son Y, Kim Y, Park J. Video-based self-assessment: Implementation and evaluation in an undergraduate nursing course. Nurse Educ Today [Internet]. 2009 [cited 2017 Jul 17];29(6):585-9. Available from: https://doi.org/10.1016/j.nedt.2008.12.008

33. Bowden T, Rowlands A, Buckwell M, Abbott S. Web-based video and feedback in the teaching of cardiopulmonary resuscitation. Nurse Educ Today [Internet]. 2012 [cited 2017 Jul 17];32(4):443-7. Available from: https://doi.org/10.1016/j.nedt.2011.04.003

34. Cardoso A, Moreli L, Braga F, Vasques C, Santos C, Carvalho E. Effect of a video on developing skills in undergraduate nursing students for the management of totally implantable central venous access ports. Nurse Educ Today [Internet]. 2012 [cited 2017 Jul 17];32(6):709-13. Available from: https://doi.org/10.1016/j.nedt.2011.09.012

35. Oh J, Kang J, De Gagne J. Learning concepts of cinenurducation: An integrative review. Nurse Educ Today [Internet]. 2012 [cited 2017 Jul 17];32(8):914-9. Available from: https://doi.org/10.1016/j.nedt.2012.03.021

36. Strand H, Fox-Young S, Long P, Bogossian F. A pilot project in distance education: Nurse practitioner students' experience of personal video capture technology as an assessment method of clinical skills. Nurse Educ Today [Internet]. 2013 [cited 2017 Jul 17];33(3):253-7. Available from: https://doi.org/10.1016/j.nedt.2011.11.014

37. Holland A, Smith F, McCrossan G, Adamson E, Watt S, Penny K. Online video in clinical skills education of oral medication administration for undergraduate student nurses: A mixed methods, prospective cohort study. Nurse Educ Today [Internet]. 2013 [cited 2017 Jul 17];33(6):66370. Available from: https://doi.org/10.1016/j.nedt.2012.01.006

38. Ha E. Attitudes toward Video-Assisted Debriefing after simulation in undergraduate nursing students: An application of $Q$ methodology. Nurse Educ Today [Internet]. 2014 [cited 2017 Jul 17];34(6):978-84. Available from: https://doi.org/10.1016/j.nedt.2014.01.003

39. Wang W, Liang Z, Blazeck A, Greene B. Improving Chinese nursing students' communication skills by utilizing video-stimulated recall and role-play case scenarios to introduce them to the SBAR technique. Nurse Educ Today [Internet]. 2015 [cited 2017 Jul 17];35(7):881-7. Available from: https://doi.org/10.1016/j.nedt.2015.02.010

40. Díaz Membrives M, Icart Isern M, López Matheu M. Literature review: Use of commercial films as a teaching resource for health sciences students. Nurse Educ Today [Internet]. 2016 [cited 2017 Jul 17];36:264-7. Available from: https://doi.org/10.1016/j.nedt.2015.10.002

41. Oh J, Steefel L. Nursing students' preferences of strategies surrounding cinenurducation in a first year child growth and development courses: A mixed methods study. Nurse Educ Today [Internet]. 2016 [cited 2017 Jul 17];36:342-7. Available from: https://doi.org/10.1016/j. nedt.2015.08.019

42. Forbes $\mathrm{H}$, Bucknall $\mathrm{T}$, Hutchinson A. Piloting the feasibility of head-mounted video technology to augment student feedback during simulated clinical decision-making: An observational design pilot study. Nurse Educ Today [Internet]. 2016 [cited 2017 Jul 17];39:116-21. Available from: https://doi.org/10.1016/j.nedt.2016.01.012

43. Forbes $\mathrm{H}$, Oprescu F, Downer T, Phillips N, McTier L, Lord B et al. Use of videos to support teaching and learning of clinical skills in nursing education: A review. Nurse Educ Today [Internet]. 2016 [cited 2017 Jul 17];42:53-6. Available from: https://doi.org/10.1016/j. nedt.2016.04.010

44. Davis L, Johnson L, Allen S, Kim P, Sims C, Pascual J et al. Practitioner Perceptions of Trauma Video Review. Int J Trauma Nurs [Internet]. 2013 
[cited 2017 Jul 17];20(3):150-4. Available from: doi: 10.1097/JTN.0b013e3182a172b6

45. Sowan A, Idhail J. Evaluation of an interactive web-based nursing course with streaming videos for medication administration skills. Int J Med Inform [Internet]. 2014 [cited 2017 Jul 17];83(8):592-600. Available from: doi: 10.1016/j.jimedinf.2014.05.004

46. Noordman J, van der Weijden T, van Dulmen S. Effects of video-feedback on the communication, clinical competence and motivational interviewing skills of practice nurses: a pretest posttest control group study. J Adv Nurs [Internet]. 2014 [cited 2017 Jul 17];70(10):2272-83. Available from: https://doi.org/10.1111/jan.12376

47. Lee N, Chae S, Kim H, Lee J, Min H, Park D. Mobile-Based Video Learning Outcomes in Clinical Nursing Skill Education. Comput Inform Nurs [Internet]. 2016 [cited 2017 Jul 17];34(1):8-16. Available from: doi: 10.1097/CIN.0000000000000183

48. Hathaway C. Using Film, Television, and Other Media to Teach Management and Leadership Concepts. Nurse Educ [Internet]. 2013 [cited 2017 Jul 17];38(6):239-40. Available from: doi: 10.1097/01.NNE.0000435269.45989.66

49. Zauderer C, Ganzer C. Cinematic Technology: the role of visual learning. Nurse Educ [Internet]. 2011 [cited 2017 Jul 17];36(2):76-9. Available from: doi: 10.1097/NNE.0b013e31820b4fbf

50. Carpenter J, Stevenson B, Carson E. Creating a Shared Experience. Nurse Educ [Internet]. 2008 [cited 2017 Jul 17];33(3):103-4. Available from: doi: 10.1097/01.NNE.0000312182.98023.86 